\title{
Different Teaching Approaches and Use of Active Learning Strategies as Tools for Inter- and Transdisciplinary Education
}

\author{
Carlos Alberto Moreira dos Santos ${ }^{1}$, Marco Antonio Carvalho Pereira ${ }^{1}$, Mariana Aranha de Souza ${ }^{2,3}$, João Paulo \\ Machado Dias ${ }^{4}$, \& Felipe Souza Oliveira ${ }^{4}$ \\ ${ }^{1}$ Programa de Pós-graduação em Projetos Educacionais de Ciências, Escola de Engenharia de Lorena, Universidade de \\ São Paulo, Lorena - SP, Brazil \\ ${ }^{2}$ Mestrado Profissional em Educação, Universidade de Taubaté, Taubaté - SP, Brazil \\ ${ }^{3}$ Programa de Pós-graduação em Gestão e Desenvolvimento Regional, Centro Universitário do Sul de Minas, Varginha - \\ MG, Brazil \\ ${ }^{4}$ Escola de Engenharia de Lorena, Universidade de São Paulo, Lorena - SP, Brazil \\ Correspondence: Carlos Alberto Moreira dos Santos, Programa de Pós-graduação em Projetos Educacionais de Ciências, \\ Escola de Engenharia de Lorena, Universidade de São Paulo, Lorena - SP, Brazil.
}

Received: December 10, 2019

doi:10.11114/ijsss.v8i2.4693

\author{
Accepted: January 16, 2020 \\ Available online: January 21, 2020 \\ URL: https://doi.org/10.11114/ijsss.v8i2.4693
}

\begin{abstract}
This work reports a review on some of the ways in which education and research can be used to solve today's complex problems by taking into account teaching and learning strategies that go beyond traditional teaching strategies. It revisits different teaching approaches and connects them directly to uni-, pluri-, multi-, inter-, and transdisciplinary attitudes, and how educational professionals think of the subject of teaching. This discussion reflects on how teachers tend to reproduce procedures they observed in their own graduation programs and why experienced teachers opt for inter- and transdisciplinary attitudes. Using a qualitative approach, this work illustrates the results from a Project-Based Learning strategy applied to a group of Major Engineering students to solve problems at the University's Campus. Participants included 25 students engaged to Physics Engineering program supervised by different faculty members, experienced undergraduate and graduate students, and technicians, who had mentored the undergraduate students' teams, all working in subjects closely related to the projects. The products developed by the teams show evidence that the students were motivated and engaged in the projects; this supports the premise that inter- and transdisciplinary approaches drive collaboration in the execution of projects, develop soft skills and permit knowledge development in an articulate and complex way thereby leading to a broader education of the students.
\end{abstract}

Keywords: teaching approaches, active learning strategies, inter- and transdisciplinarity

\section{Introduction}

Nowadays, discussions have focused on different branches of knowledge regarding the use of alternatives to traditional teaching. Fundamentals of socioconstructivism (Vygotsky, 1999; Coll, 2004), meaningful learning (Ausubel, 1963), autonomy and motivation (Freire, 1996; Dikinson, 1995; Reeve, Bolt \& Cai, 1999; Ryan \& Deci, 2000), and digital information and communication media (Castells, 1996), have all been used to establish new active teaching and learning strategies.

Along with this, there have been different teaching practices in the classroom due to the scope of the curriculum which could be uni-, pluri-, multi-, inter-, or transdisciplinary (Sommerman, 2006). Many groups all over the world have conducted research and education studies on these different scopes. Some of the most recognized authorities on these subjects are Basarab Nicolescu (Niculescu \& Ertas, 2013), Yves Lenoir (Lenoir \& Hasni, 2016), Edgar Morin (Morin, 1999), Ivani Fazenda (Fazenda, 2014), Hilton Japiassu (Japiassu, 2006; Carneiro, 2018), among others.

Therefore, literature on the subject is extensive and generally overlaps different fields of knowledge. Nevertheless, there has been no consensus on the forms of action and their scope limits, especially regarding the application of inter- and transdisciplinary approaches (Bernstein, 2015; Ertas, Nicolescu \& Gehlert, 2016; Fazenda, 2008). This discussion is nothing new and was initiated about 50 years ago. To illustrate this, at an event on multi- and interdisciplinarity in the 
1970s, Jean Piaget coined the term transdisciplinarity (Piaget, 1972). This later culminated with the Charter of Transdisciplinarity (Freitas, Morin \& Nicolescu, 1994) and the Manifest of Transdisciplinarity (Nicolescu, 2002), which dealt with social development, equality of human rights and others issues, in addition to addressing the of quality of education.

The ability of students to develop competencies to solve complex problems are among the fundamental aspects in discussions of teaching and research practices. Some authors have documented that pluri- or multidisciplinary fields cannot solve the complex problems in today's world, this supports the need for inter- and transdisciplinary educational attitudes (Fazenda, 2008; Ertas, 2018; Morin, 1999). Padurean \& Cheveresan (2010) consider transdisciplinarity the basis of the four pillars of 21st Century Education, since it takes into account teaching and learning strategies which consider the dimensions of "learning to know", "learning to do", "learning to be", and "learning to live together", as pointed out by Delors and collaborators (Delors, 1996, 2013).

Additionally, according to Ertas (2018):

Transdisciplinarity can be defined as the practice of acquiring new knowledge through education, research, design, and production with a broad emphasis on complex problem solving, and the use of knowledge and techniques from multiple scholarly disciplines (Ertas 2018, p. 77).

Thus, any discussion involving the type of disciplinary approach will certainly impact on the establishment of a new paradigm in teaching and learning processes, in solving academic problems, while taking formal courses (i.e. educational problems) (Dewey, 1938), as well as in solving real-world problems (i.e. research and social problems) (Ertas, 2018).

Using a qualitative approach, this article reviews the epistemological and methodological assumptions that involve the concepts of uni-, pluri-, multi-, inter-, and transdisciplinarity, by which the teachers can act. The article also reports a case study on the use of Project-Based Learning as an example of inter- and transdisciplinary approach, which was used to teach a group of undergraduate students drawn from a Physical Engineering program.

\section{The Different Teaching Strategies}

One of the reasons for the creation of knowledge areas, different disciplines, and college programs was based on the fact that it was thought that the organization of knowledge in smaller fractions would lead to the development of more specialized knowledge in one area, and consequently would facilitate learning. This resulted in the creation of specialized programs towards the end of the $20^{\text {th }}$ century. A striking example of this is engineering programs. In Brazil, for instance, in 1973 there were 21 different specializations, increasing to 35 in 1995 and to 50 in 2005 (Oliveira, 2005; Oliveira, Almeida, Carvalho \& Pereira, 2013). However, many authors have argued that uni-, pluri-, and multidisciplinary education and research did not take into account the complexity of the problems that exist at the beginning of this century. This needs teaching and learning attitudes that put together inter- and transdisciplinary aspects (Ertas, 2018).

To exemplify these different ways of teaching and learning, Figure 1 schematically displays the unidisciplinary thoughts of four different professionals about an object, a book.

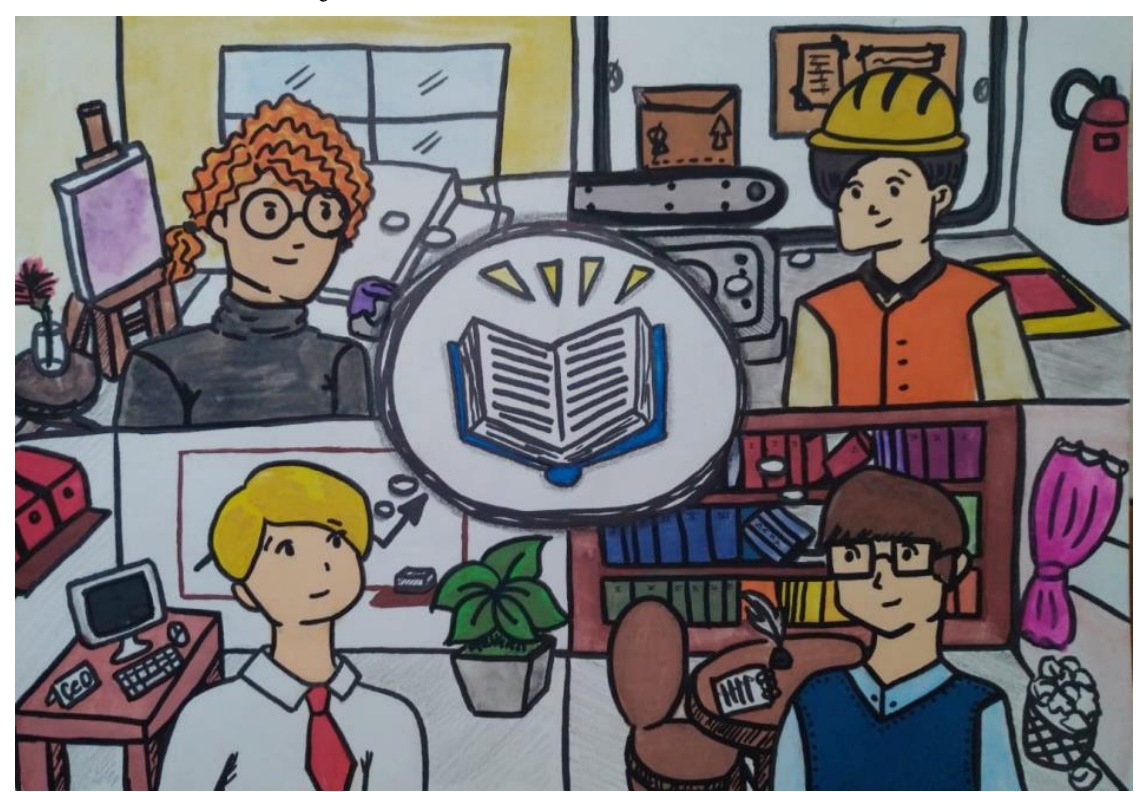

Figure 1. Representation of different thoughts of four professionals about a book 
The four professionals are a Cartoonist (upper left panel), an Engineer (upper right panel), a Business administrator (lower left panel), and a Writer (lower right panel). All of them work in the book creation, production and distribution chain. Based on their professional fields, each one has different thoughts on the same object of work, which are summarized in Chart 1.

Chart 1. The thoughts of the different professionals mentioned in Figure 1.

\begin{tabular}{cc}
\hline Professional & Unidisciplinary thoughts \\
\hline Cartoonist & Make drawings to illustrate books \\
Engineer & Work at the book production line \\
Business administrator & Manage book production and distribution \\
Writer & Write texts in order to report the subject in books \\
\hline
\end{tabular}

If the thoughts of each of the professionals is unidisciplinar, as shown in Chart 1, they will not be able to explain to any individual the relationship between the object of work and other subject areas. For a todays' student, such thoughts will not address their learning needs. For example, a young graduate student entering the job market needs to have knowledge that goes far beyond that of his/her teachers' unidisciplinary field. Nevertheless, due to the existence of different subjects and different approaches to teaching and learning, the student ends up getting a better education than the sum of the unidisciplinary fields of each teacher. Thus, having teachers with more inter- or transdisciplinary attitudes probably will better equip the students for the job market.

Therefore, is quite reasonable nowadays for a professional of any field to have knowledge that goes well beyond his/her unidisciplinary field of expertise. It is not uncommon to find a writer who knows about the production costs of a book, recognizes social and environmental impacts related to this production, and uses digital media for writing the books. Furthermore, an engineer is expected to know details of the quality of the papers that will make up the printing of a book and even the best way to display it for sale in a bookstore window. This kind of broad knowledge will have a very positive impact on solving today's problems and the overall education of students.

Based on above reflections on unidisciplinary thoughts, it is possible to summarize how teaching strategies are used. Chart 2 lists disciplinary fields and relate them to the teacher's perceptions, as well as to the different forms of teaching approaches.

Chart 2. Disciplinary fields, different teachers' perceptions, and different teaching approaches.

\begin{tabular}{|c|c|c|}
\hline Disciplinary field & How teachers see the object of teaching & Teaching approach \\
\hline Unidisciplinary & Has specific knowledge about the subject matter & $\begin{array}{l}\text { Teaches as if only one field of knowledge } \\
\text { existed }\end{array}$ \\
\hline Pluridisciplinary & $\begin{array}{l}\text { Recognizes the existence of other fields of } \\
\text { knowledge that involve the object of teaching }\end{array}$ & $\begin{array}{l}\text { Teaches the content in a unidisciplinary way, } \\
\text { but knows the existence of other fields of } \\
\text { knowledge }\end{array}$ \\
\hline Multidisciplinary & $\begin{array}{l}\text { Looks at the object of teaching in a } \\
\text { unidisciplinary way, but is able to make students } \\
\text { interact with other fields of knowledge }\end{array}$ & $\begin{array}{l}\text { Teaches the content of your knowledge, but } \\
\text { cares about the student learning on other } \\
\text { subjects }\end{array}$ \\
\hline Interdisciplinary & $\begin{array}{l}\text { Deals with the object of teaching in broader way } \\
\text { because is routinely interacting with } \\
\text { professionals from other fields of knowledge }\end{array}$ & $\begin{array}{l}\text { Teaches the content of his/her subject as well as } \\
\text { others by appropriating knowledge from other } \\
\text { areas through collaboration with different } \\
\text { professionals }\end{array}$ \\
\hline Transdisciplinary & $\begin{array}{l}\text { Looks at the object of teaching in very broad } \\
\text { way, considering aspects in all fields of } \\
\text { knowledge that involve the existence of the } \\
\text { object }\end{array}$ & $\begin{array}{l}\text { Teachers concerned with all updated aspects of } \\
\text { knowledge in the areas of Exact, Biological, } \\
\text { and Human Sciences }\end{array}$ \\
\hline
\end{tabular}

In addition to providing insight into the comprehensiveness of each teaching approach, Chart 2 provides an additional perspective: the maturity of teachers throughout the working years. This Chart suggests that a teacher with little experience tends to have an attitude uni- or pluridisciplinary practices, which is explained by the fact that this teacher 
tends to reproduce the practices he/she experienced during his or her college classes (Day, 1999). Thus, less experienced teachers should be motivated to move forward gradually from uni- and pluri- to inter- and transdisciplinary approaches as soon as possible, however, one has to keep in mind this is a time-consuming process which cannot be attained by a young teacher in a short period of time.

With time, a mid-career teacher begins to apply a more multidisciplinary attitude, which favors the exchange and obtaining of information from fields other than that of his/her initial college graduation. Because of this attitude, these teachers end up moving towards more inter- and transdisciplinary approaches, allowing them to become daring and bringing fundamentals from other areas of knowledge to their own teaching practices, as well as drawing on aspects of everyday life, an attitude of a mature individual. Because of this process, the more experienced teacher ends up providing a more complete education for students; an approach more compatible with the issues of 21st century complexity.

These aspects are important for the continuous development of professionals in education, since those at the starting point of their career cannot match to those who are more mature. Furthermore, broader formative opportunities, which allow teachers to reflect on their areas of knowledge and in different contexts, ought to be considered as very relevant in today's world (Auerbach \& Andrews, 2018; Day, 1999; Deslauriers, Schelew \& Wieman, 2011; Shulman, 2016).

\section{Active Learning Strategies and Their Relevance for the Today's Complex Problem Solving}

Based on discussions about teaching strategies documented so far, there is reasonable agreement among teachers on the use active learning strategies that supposedly develop soft skills, $i . e$. those related to behavior, interpersonal, and collaborative actions, which are relevant for promoting inter- and transdisciplinary attitudes in students. Thus, assuming that the development of soft skills are parts of the pillars of 21st century education, and that inter- and transdisciplinary attitudes form the basis of these pillars, as suggested by Padurean \& Cheveresan (2010), it is imperative that educational institutions should make their teachers overcome difficulties faced with the use of these skills and attitudes. Some of these difficulties are related to the existence of only traditional infrastructure, such as conventional classrooms, or disagreement in using active learning strategies, either by teachers' fear of placing themselves in unfamiliar situations, which is very common in these type of strategies, or due to the possible greater work teachers may have in performing student-centered activities.

Additionally, it is clear that, in the case of Engineering, active learning strategies involving collaborative team activities are the best for simulating the real situations faced by engineers in today's world (Graaff, Saunders-Smits \& Nieweg, 2005). Thus, we highlight Project-Based Learning (Pereira, Barreto \& Pazeti., 2017; Stozhko, Bortnik, Mironova, Tchernysheva \& Podshivalova., 2015; Treadwell, 2018), Problem-Based Learning (Graaff \& Kolmos, 2007; Yadav, Subedi, Lundeberg \& Bunting, 2011), Team-Based Learning (Koles, Stolfi, Borges, Nelson \& Parmelle, 2010; Parmelee, Michaelsen, Cook \& Hudes, 2012; Zhang, Wu \& Li, 2018), and Design Thinking (Glen, Suciu, Baughn \& Anson, 2015; Design Thinking for educators, 2013; Ingle, 2013), among others.

Specifically, in 2010, UNESCO (2010, p.6) proposed "transforming engineering education, curricula, and teaching methods to emphasize relevance and problem-solving approach to engineering". UNESCO (2010) also emphasized that engineering curricula should be based on activities that are relevant to students, with a focus on learning through projects.

Project-Based Learning is an active learning strategy in which students' teams work on projects based on real problems, aimed developing students' technical and soft skills. It is a strategy in which students find themselves facing tangible problems that ought to be solved using technical knowledge (Lehmann, Christensen, Du \& Thrane, 2008; English \& Kitsantas, 2013).

For engineering undergraduate programs, Project-Based Learning strategy is considered one of the most effective ways to prepare students for the challenges in their future career (Jollands, Jolly \& Molyneaux, 2012).

\section{Case Study}

The section describes a case study considered inter- and transdisciplinary in the discipline of Electronic Materials and Devices, offered in the second semester of 2018 to 25 student-majors from the Physical Engineering program at the University of São Paulo at Lorena.

The theoretical contents of the discipline were carried out using tools and strategies described in a previously published work (dos Santos, Pereira, Barreto, de Souza \& Cicarelli, 2019). The option here was to adopt the Project-Based Learning as an active learning strategy.

The students were divided into 5 teams of 5 members each, decided by lot, to elaborate and execute the projects. The teams had a multidisciplinary group of faculty members, experienced undergraduate and graduate students, technicians from different backgrounds, capable of supporting the development of conceptual contents and assisting the technical 
procedures necessary for the execution of the projects. All the projects were required to be low cost and related to University Campus issues.

The teams had to consider the following aspects when establishing the projects:

i) A close relationship between the projects and the contents of the discipline, the undergraduate program, and the general education of students enrolled in the subject;

ii) the competencies and skills of the supervisory team members, consisting of monitors, graduate students, technicians, maintenance assistants, teachers of other disciplines related to the projects, and the own profile of the subject's teacher;

iii) The project ought to be feasible within a specified time schedule;

iv) The project ought to be related to real problems of the student's daily life;

$v$ ) The elaboration and execution of the projects should be planned in a way that do not diminish the hard content to be learned from the discipline; and

vi) The student's learning should be evaluated individually through two written exams.

The assessment of each student's learning was based on two individually-written exams related to the hard content of the discipline, as well as team project development through presentation of the results. The progress of the projects was monitored during traditional and online classes through the Cuboz social education network (de Souza, Bussolotti, Ribeiro \& da Cunha, 2019; dos Santos et al., 2019).

The following projects were carried out throughout the semester:

i) Mounting of security cameras;

ii) Studying and testing of a "magic carpet" for energy collection using piezoelectric materials;

iii) Development of energy saving lighting sensors;

iv) Development of motion sensors with alarms; and

v) Solar panel assembly for energy collection and use.

Figure 2 shows images of the final assembly of the project related to solar panel, where one can see two students interacting with two technicians (left picture) and the system running with a light illuminating the Campus location chosen by the team (right picture).
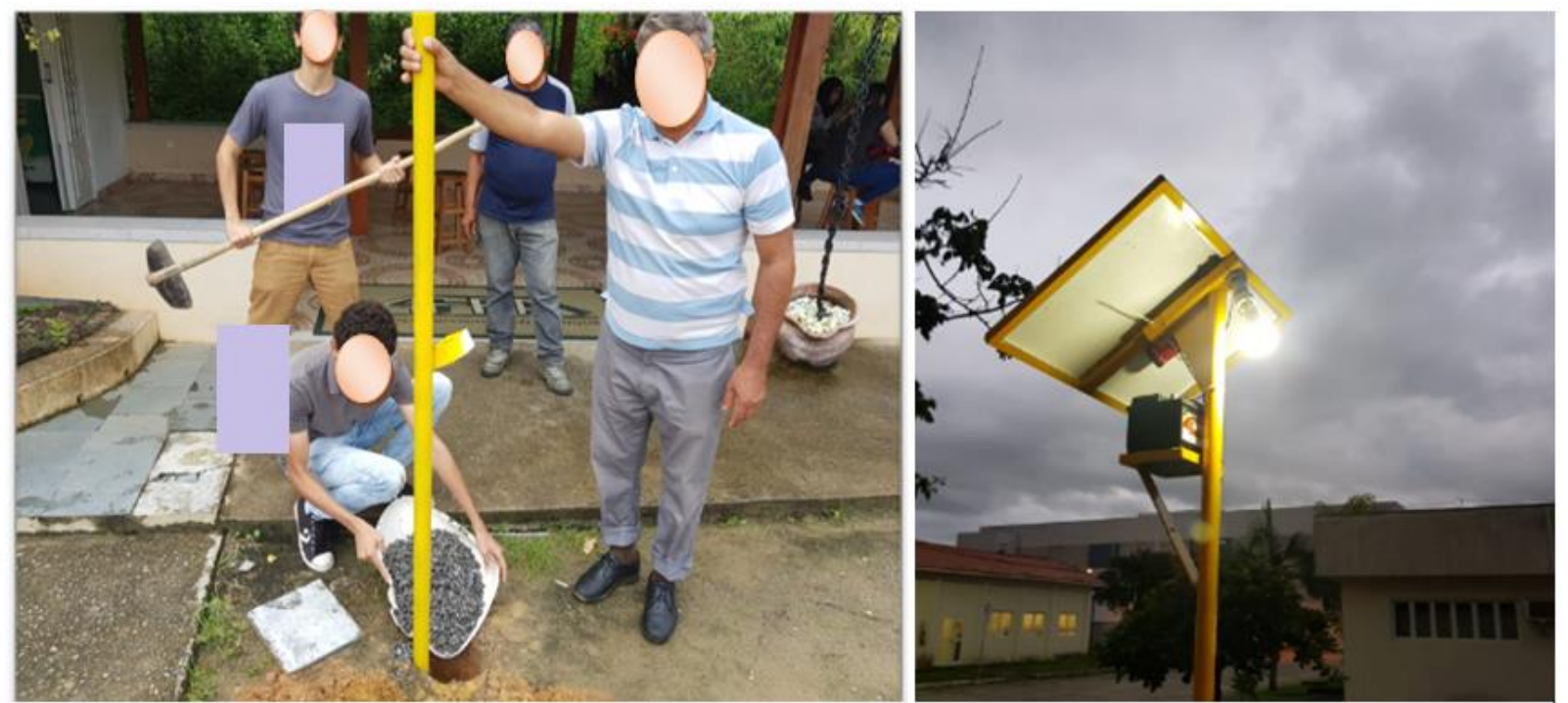

Figure 2. Images of the solar panel project in its final assembly. Some parts of the images were covered to protect identities and advertisements

The initial aspects of the projects ought to have considered the following issues:

i) The location of the project should be in the University Campus;

ii) The devices to be used, preferably low cost or reuse materials, and free software;

iii) The quotations for the devices and viability of setting up the proposed system; 
iv) Purchasing the devices;

v) Testing and obtaining data on the performance of assembled equipment;

vi) Finalizing the project within an established schedule; and

vii) Demonstrating the viability of the project economically, taking into account sustainability and safety issues on the University Campus.

Based on the activities developed by the teams during the elaboration and execution of the projects the following interand transdisciplinary activities were observed:

i) Use of concepts from several other discipline subjects, such as General Physics, Mechanics, Welding, Technical Drawing, Electricity and Magnetism, and Electronics and Instrumentation;

ii) Bibliographic search in Portuguese and English;

iii) Preparation of scientific assays;

iv) Use of social networks (Cuboz and WhatsApp) and videos (YouTube);

v) Teamwork;

vi) Development of cooperation and collaboration activities;

vii) Interaction with employees of all levels of training;

viii) Development of leadership aspects;

ix) Oral presentations;

$x$ ) Development of planning aspects and commitment with the execution schedule;

xi) Perception of viability;

xii) Importance of the project for the sustainability and safety of the University Campus; and

xiii) Demonstration of the degree of individual and team satisfactions during the execution of the project and on the days of partial and final presentations.

Results of the executed projects showed that the combination of all the aspects above mentioned were compatible with the development of inter- and transdisciplinary projects, which are important for the teaching approaches that involve problem solving of greater complexity.

\section{Final Remarks}

Based on unidisciplinary thoughts of several educational professionals, different teaching approaches have been documented. Experienced teachers tend to adopt inter- and transdisciplinary attitudes more frequently. These approaches are considered more appropriate for students that must learn how to solve complex world problems of this century. On the other hand, younger teachers tend to use educational strategies that are more uni- or pluridisciplinary related to their own previous experience as students. This suggests that teachers ought to be aware of these approaches and attitudes.

To provide an opportunity for students to be exposed to multi-, inter-, and transdisplinary actions, Project-Based Learning methodology was adopted to teach five teams of Major Engineering students to solve problems at the University Campus. The projects were mentored by undergraduate and graduate students, technicians, and faculty members of project-related subjects. The team of students had to elaborate a sketch of the project, source and purchase the items required to build the system, and demonstrate how the system could work to address a problem. Students' motivation and engagement were assessed using their comments and satisfaction during the conduct of the projects. Project-Based Learning was evidently a teaching strategy that promoted active learning and permitted inter- and transdisciplinary collaboration. Therefore, teaching went beyond the uni- and pluridisciplinary approaches and developed the four pillars of 21st Century Education, proposed by Delors (1996), especially the teamwork skills, and collaboratively solving real-world complex problems.

\section{Acknowledgements}

The authors thank the Engineers Leandro O. Bettoni and Marco A. R. Pinto, and the several Technicians of the University of São Paulo at Lorena. Special thanks is given to Débora A. I. Yoshioka for the drawing of the Figure 2.

\section{References}

Auerbach, A. J. J., \& Andrews, T. C. (2018). Pedagogical knowledge for active-learning instruction in large undergraduate biology courses: a large-scale qualitative investigation of instructor thinking. International Journal of STEAM-Education, 5(19), 1-25. https://doi.org/10.1186/s40594-018-0112-9

Ausubel, D. P. (1963). The psychology of meaningful verbal learning. New York. NY. Grune \& Stratton. 
Bernstein, J. H. (2015). Transdisciplinarity: A review of its origins, development, and current issues. Journal of Research Practice, 11(1), 1-20. Retrieved from http://jrp.icaap.org/index.php/jrp/article/view/510/412

Carneiro, L. (2018). Hilton Ferreira Japiassu (1934-2015). Interdisciplinaridade. Retrieved from https://revistas.pucsp.br/interdisciplinaridade/article/view/25480

Castells, M. (1996). The Rise of the Network Society. The Information Age. Cambridge, MA. Blackwell

Coll, C. (2004). Construtivismo e educação: a concepção construtivista do ensino e da aprendizagem [Constructivism and education: the constructivist conception of teaching and learning]. In Coll, C.; Marchesi, A., \& Palacios, J. Desenvolvimento psicológico e educação [Psychological development and education]. pp 107-130. Porto Alegre. Artmed.

Day, C. (1999). Developing Teachers: the challenges of Lifelong Learning. Bristol, PA. Falmer Press.

de Souza, M. A., Bussolotti, J. M., Ribeiro, S. L. S., \& da Cunha, V. M. P. (2019). O uso de plataformas digitais e flipped classrrom em uma disciplina no Mestrado Profissional em Educação [The use of digital plataforms and flipped classroom in a discipline of the professional Master Program in Education]. Revista Ciências Humanas, 12, 189-207. https://doi.org/10.32813/2179-1120.2019.v12.n2.a556

Delors, J. (1996). Learning: the Treasure Within. International Commission on Education for the Twenty-first Century. UNESCO Publishing. https://doi.org/10.7788/ijbe.1996.24.1.253

Delors, J. (2013). The treasure within: Learning to know, learning to do, learning to live together and learning to be. What is the value of that treasure 15 years after its publication? Int. Rev. Educ., 59, 319-330. https://doi.org/10.1007/s11159-013-9350-8

Design Thinking para educadores. [Design Thinking for educators]. (2013). Instituto Educadigital. São Paulo. Retrieved from https://www.dtparaeducadores.org.br/site/sobre-o-material/

Deslauriers, L., Schelew, E., \& Wieman, C. (2011). Improved Learning in a Large-Enrollment Physics Class. Science, 332(6031), 862-865. https://doi.org/10.1126/science.1201783

Dewey, J. (1938). Experience and Education. New York. NY. Collier Books.

Dickinson, L. (1995). Autonomy and Motivation - A Literature Review. System, 23(2), 165-174. https://doi.org/10.1016/0346-251X(95)00005-5

dos Santos, C. A. M., Pereira, M. A. C., Barreto, M. A. M., de Souza, M. A., \& Cicarelli, P. O. (2019). CEMTRAL: Uma Nova Metodologia Híbrida de Ensino e Aprendizagem [CEMTRAL: a new hybrid methodology for teaching and learning]. Revista Brasileira de Aprendizagem Aberta e a Distância, 18,

18. https://doi.org/10.17143/rbaad.v18i1.293

English, M. C., \& Kitsantas, A. (2013). Supporting Student Self-Regulated Learning in Problem- and Project-Based Learning. Interdisciplinary Journal of Problem-Based Learning, 7(2), 127-150. https://doi.org/10.7771/1541-5015.1339

Ertas, A. (2018). Transdisciplinary Engineering Design Process. Hoboken, NJ. John Wiley and Sons.

Ertas, A., Nicolescu, B., \& Gehlert, S. J. (Eds.). (2016). Convergence: Transdisciplinary Knowledge \& Approaches to Education and Public Health. The Atlas Publishing. Retrieved from http://basarab-nicolescu.fr/BOOKS/ConvergenceTransdisciplinaKnowledgeApproaches.pdf

Fazenda, I. C. A. (Ed). (2008). O que é Interdisciplinaridade? [What is Interdisciplinarity?] São Paulo. Cortez.

Fazenda, I. C. A. (Ed). (2014). Interdisciplinaridade: pensar, pesquisar e intervir [Interdisciplinarity: think, research and intervene]. São Paulo. Cortez.

Freire, P. (1996). Pedagogia da Autonomia: saberes necessários à prática educativa. [Pedagogy of Autonomy: necessary knowledge to educational practice]. São Paulo. Paz e Terra.

Freitas, L., Morin, E., \& Nicolescu, B. (1994). Charter of Transdisciplinarity. (adopted at the First World Congress of Trandisciplinarity, Portugal). Retrieved from https://ciret-transdisciplinarity.org/chart.php\#pt

Glen, R., Suciu, C., Baughn, C., \& Anson, R. (2015). Teaching Design Thinking in business schools. The International Journal of Management Education, 13(2), 182-192. https://doi.org/10.1016/j.ijme.2015.05.001

Graaff, E., \& Kolmos, A, (2007). Management of change implementation of problem-based and project-based learning in engineering. Rotterdam. Sense Publishers. https://doi.org/10.1163/9789087900922_002

Graaff, E., Saunders-Smits, G., \& Nieweg, M. (2005). Research and Practice of Active Learning in Engineering 
Education. Amsterdam. Amsterdam University Press. https://doi.org/10.5117/9789085550914

Ingle, B. R. (2013). Design Thinking for Entrepreneurs and Small Businesses: Putting the Power of Design to Work. New York. NY. Apress. https://doi.org/10.1007/978-1-4302-6182-7

Japiassu, H. (2006). O sonho transdisciplinar: e as razões da filosofia. [The transdisciplinary dream: and the reasons of philosophy]. Rio de Janeiro. Imago.

Jollands, M., Jolly, L., \& Molyneaux, T. (2012). Project-based learning as a contributing factor to graduates’ work readiness. European Journal of Engineering Education, 37(2), 143-154. https://doi.org/10.1080/03043797.2012.665848

Koles, P. G., Stolfi, A., Borges, N. J., Nelson, S., \& Parmelle, D. X. (2010). The impact of team-based learning on medical students' academic performance. Academic Medicine, 85(11), 1739-1745. https://doi.org/10.1097/ACM.0b013e3181f52bed

Lehmann, M., Christensen, P., Du, X., \& Thrane, M. (2008). Problem-oriented and project-based learning (POPBL) as an innovative learning strategy for sustainable development in engineering education. European Journal of Engineering Education, 33(3) 283-295. https://doi.org/10.1080/03043790802088566

Lenoir, Y., \& Hasni, A. (2016). Interdisciplinarity in Primary and Secondary School: Issues and Perspectives. Creative Education, 7, 2433-2458. https://doi.org/10.4236/ce.2016.716233

Morin, E. (1999). Seven complex lessons in education for the future. Unesco. Retrieved from https://unesdoc.unesco.org/ark:/48223/pf0000117740

Nicolescu, B. (Ed.). (2002). Manifest of Transdisciplinarity, translated by K. Claire Voss (Albany. State University of New York Press), pp. 147-152. Retrieved from http://inters.org/Freitas-Morin-Nicolescu-Transdisciplinarity

Nicolescu, B., \& Ertas, A. (Eds.). (2013). Transdisciplinary: Theory \& Practice. The Atlas Publishing. Retrieved from http://basarab-nicolescu.fr/BOOKS/Transdisciplinary_Theory\&Practice-2013-1.pdf

Oliveira V. F., Almeida N. N., Carvalho D. M., \& Pereira, F. A. A. (2013). Um estudo sobre a expansão da Formação em Engenharia no Brasil. [A study on the expansion of Engineering Training in Brazil]. Revista de Ensino de Engenharia, 32(3), 37-56. https://doi.org/10.15552/2236-0158/abenge.v32n3p37-56

Oliveira, V. F. (2005) Crescimento do Número de Cursos e de Modalidades de Engenharia: Principais Causas e Consequências. [Number of Engineering Courses and Modalities Growth: main causes and consequences]. Anais do Congresso Brasileiro de Ensino de Engenharia. Campina Grande. PB.

Padurean, A., \& Cheveresan, C. T. (2010). Transdisciplinary in Education. Journal Plus Education, 6(1), $127-133$.

Parmelee, D., Michaelsen, L. K., Cook, S., \& Hudes, P. D. (2012). Team-based learning: a practical guide: AMEE guide no. 65. Medical teacher, 34(5), e275-e287. https://doi.org/10.3109/0142159X.2012.651179

Pereira, M. A. C., Barreto, M. A. M., \& Pazeti, M. (2017). Application of Project-Based Learning in the first year of an Industrial Engineering Program: lessons learned and challenges. Production, 27 spe. https://doi.org/10.1590/0103-6513.223816

Piaget, J. (1972). L'Épistémologie des relations interdisciplinaires in Transdisciplinarité - Problèmes d'enseignement et de recherche dans les Universités. [The Epistemology of Interdisciplinary relations in transdisciplinarity - teaching and research problems in Universities]. O.C.D.E., Paris.

Reeve, J., Bolt, E., \& Cai, Y. (1999). Autonomy-Supportive Teachers: How They Teach and Motivate Students. Journal of Educational Psychology, 91(3), 537-548. https://doi.org/10.1037/0022-0663.91.3.537

Ryan, R. M., \& Deci, E. L. (2000). Intrinsic and Extrinsic Motivations: Classic Definitions and new Directions. Contemporary Educational Psychology, 25, 54-67. https://doi.org/10.1006/ceps.1999.1020

Shulman, L. S. (2016). Educational Innovation with Open Eyes and No Excuses: the challenges and opportunities of learning from experience. Revista Gestión de La Innovación en Educación Superior. REGIES. I. p.13-26. Retrieved from http://ojs.inacap.cl/index.php/regies/article/view/16/38

Sommerman, A. (2006). Inter ou Transdisciplinaridade? Da fragmentação disciplinar ao novo diálogo entre os saberes. [Inter or Transdisciplinarity? From disciplinary fragmentation to the new dialogue between knowledge]. São Paulo. Paulus.

Stozhko, N., Bortnik, B., Mironova, L., Tchernysheva, A., \& Podshivalova, E. (2015). Interdisciplinary project-based learning: technology for improving student cognition. Research in Learning Technology, $23,27577$. https://doi.org/10.3402/rlt.v23.27577 
Treadwell, S, M. (2018). Making the Case for Project-based Learning (PBL) in Physical Education. Journal of Physical Education, Recreation \& Dance, 89(1), 5-6. https://doi.org/10.1080/07303084.2018.1393225

UNESCO. (2010). Engineering: Issues Challenges and Opportunities for Development. Retrieved from http://unesdoc.unesco.org/images/0018/001897/189753e.pdf

Vygotsky, L. S. (1999). A formação social da mente. [The social formation of mind]. São Paulo. Martins Fontes.

Yadav, A., Subedi, D., Lundeberg, M. A., \& Bunting, C. F. (2011). Problem-based learning: Influence on students' learning in an electrical engineering course. Journal of Engineering Education, 100(2), 253-280. https://doi.org/10.1002/j.2168-9830.2011.tb00013.x

Zhang, J., Wu, W., \& Li, H. (2018). Enhancing Building Information Modeling Competency among Civil Engineering and Management Students with Team-Based Learning. Journal of Professional Issues in Engineering Education and Practice, 144(2). https://doi.org/10.1061/(ASCE)EI.1943-5541.0000356

\section{Copyrights}

Copyright for this article is retained by the author(s), with first publication rights granted to the journal.

This is an open-access article distributed under the terms and conditions of the Creative Commons Attribution license which permits unrestricted use, distribution, and reproduction in any medium, provided the original work is properly cited. 